\title{
KAJIAN TEKNOLOGI PEMANFAATAN BIOGAS \\ POME (PALM OIL MILL EFFLUENT) KE BOILER
}

\section{STUDY OF THE TECHNOLOGY OF UTILIZING BIOGAS FROM PALM OIL MILL EFFLUENT (POME) TO BOILER}

\author{
Bambang Sucahyo, Dwi Lukman H, Rohmadi Ridlo, \\ Tyas Puspita R, Erna Rosmala S \\ Pusat Teknologi Sumberdaya Energi dan Industri Kimia, Badan Pengkajian \\ dan Penerapan Teknologi \\ Gedung Energi Klaster 5, PUSPIPTEK Serpong, Tangerang Selatan 15314 \\ e-mail : b.sucahyo61@gmail.com
}

\begin{abstract}
Abstrak
PTPN V di Propinsi Riau, merencanakan kajian teknis untuk penerapan teknologi Biogas to Boiler untuk memaksimalkan pemanfaatan Biogas, khususnya di PKS Sei Pagar. Kajian tersebut bertujuan untuk mensubstitusi Cangkang pada Boiler/ Ketel Uap melalui skema Model Pemanfaatan Biogas POME ke Boiler pada Pabrik Kelapa Sawit. Selain kajian teknis, kajian keekonomian dan lingkungan dilakukan dalam kaitan studi banding ke beberapa PKS di wilayah Sumatera dan Kalimantan. Skema Model Pemanfaatan Biogas POME ke Boiler pada Pabrik Kelapa Sawit menggunakan beberapa komponen, seperti : Blower, Sistem Pemipaan, Valve Train, Gas Burner (Single Burner), Forced Draft Fan, dan Control Panel (PHB). Dari hasil studi tersebut, jumlah cangkang yang dapat digantikan dengan biogas POME pada pembakaran di Boiler sebanyak 6.549,3 ton per tahun. Jika cangkang tersebut dapat dijual dengan harga sebesar Rp 4.000 per $\mathrm{kg}$ atau $\mathrm{Rp} 400.000$ per ton, maka pendapatan yang diperoleh dari hasil penjualan cangkang sekitar Rp 2,62 Milyar. Model Pemanfaatan tersebut dapat dikembangkan dan diterapkan untuk mendukung penerapan teknologi Biogas to Boiler di Pabrik Kelapa Sawit yang ada di Indonesia.
\end{abstract}

Kata Kunci : Ketel Uap/ Boiler, Blower, Sistem Pemipaan, Valve Train, Gas Burner (Single Burner), Forced Draft Fan, Control Panel

\begin{abstract}
PTPN V in Riau Province, planning the implementation of technical study of Biogas to Boiler technology to maximize the use of Biogas in particular the Sei Pagar Mill. The study aims to substitute shells for steam boilers/ kettle through the scheme of using biomass POME to boilers at palm oil mills. In addition to technical studies, economic and environment studies are carried out in comparative studies on several Mill $s$ in Sumatra and Kalimantan. Utilization Model Scheme. Biogas POME to Boilers at Palm Oil Mill by applying Biogas to Boiler technology includes several components of equipment, such as: Blower, Piping System, Valve Train, Gas Burner (Single Burner), Forced Draft Fan, and Control Panel (PHB).From the study, then number of shells that can be replaced with Biogas POME in the Boiler combustion is 6,549.3 ton per annum. If the shells can be sold at the price of IDR 4,000 per kg or IDR 400,000 per tonne, the income obtained from the sale of shells is around IDR 2,62 billion. The Utilization Model of Biogas POME can be developed and implemented to support the application of Biogas to Boiler technology at Palm Oil Mills in Indonesia.
\end{abstract}

Keywords: Steam Boiler/ Boiler, Blower, Piping System, Valve Train, Gas Burner (Single Burner), Forced Draft Fan, and Control Panel

Diterima (received) : 26 November 2019 , Direvisi (revised) : 01 Maret 2019 ,

Disetujui (accepted) : 06 Maret 2019 


\section{PENDAHULUAN}

Kebijakan energi Indonesia tertuang dalam Peraturan Pemerintah Nomor 79 Tahun 2014 tentang Kebijakan Energi Nasional (KEN). Kebijakan pengelolaan energi didasarkan pada prinsip keadilan, berkelanjutan, dan berwawasan lingkungan guna terciptanya kemandirian energi dan ketahanan energi nasional. Terkait dengan hal tersebut, Kebijakan Energi Nasional mentargetkan kontribusi Energi Baru Terbarukan (EBT) sebesar 23\% dari bauran energi nasional pada tahun 2025 mendatang ${ }^{1}$.

Terkait dengan pemberdayaan sumber daya energi terbarukan, maka pemanfaatan biomassa berbasis kepada tanaman sawit menjadi opsi strategis sebagai bahan baku untuk produksi bahan bakar alternatif di masa mendatang. Indonesia merupakan produsen Crude Palm Oil (CPO) terbesar di dunia saat ini, yakni sekitar 35 juta ton per tahun. Pabrik kelapa Sawit mengolah TBS, dan menghasilkan produk minyak kelapa sawit (Crude Palm Oill CPO), minyak kernel (Palm Kernel Oill PKO). Dari kegiatan pengolahan CPO menghasilkan limbah padat seperti TKS, cangkang dan serabut, serta limbah cair (Palm Oil Mill Effluent/ POME). TKS umumnya digunakan untuk pupuk/ land application dengan mengembalikannya ke lahan perkebunan atau digunakan untuk menimbun tanah di lahan perkebunan.

POME merupakan salah satu produk samping berbentuk cairan kekuningan pekat dengan bau ofensif yang berbeda dan ditandai oleh nilai-nilai COD (Chemical Oxygen Demand) dan BOD (Biological Oxygen Demand) di kisaran 35.000 - $120.000 \mathrm{mg} / \mathrm{L}$ dan 25.000 $65.000 \mathrm{mg} / \mathrm{L}$. Potensi limbah cair tersebut sangat besar dan dimungkinkan untuk dikembangkan menjadi produk bermanfaat seperti Biogas POME yang dapat dimanfaatkan untuk menghasilkan listrik, panas, dan substitusi bahan bakar.

Pemanfaatan Biogas POME sebagai bahan bakar membutuhkan treatment untuk mengurangi kadar air, dan terutama $\mathrm{H}_{2} \mathrm{~S}$ yang memenuhi ambang batas pada pembakaran di Gas Engine (<200 ppm) dan pembakaran pada
Burner di Boiler ( $<1000$ ppm), sehingga semakin banyak dimanfaatkan.

Umumnya PKS memanfaatkan seluruh serabut dan sebagian cangkang untuk bahan bakar boiler PKS guna menghasilkan uap air untuk keperluan proses PKS dan membangkitkan energi listrik. Sebagian cangkang yang tidak digunakan sebagai bahan bakar, dijual ke pasar di wilayah Sumatera umumnya dengan harga Rp 400.000 $500.000 /$ ton-cangkang 2,3 .

Pada PKS Sei Pagar yang beroperasi di bawah manajemen PTPN V, terdapat dua unit boiler di mana satu unit beroperasi dan satu unit untuk standby. Boiler yang digunakan di PTPN V, seperti di PKS Sei Pagar, Terantam, Tandun dan lainnya, menggunakan Boiler Takuma $(\mathrm{N}$ 600SA), dengan parameter Tekanan outlet (P2) 2,2 MPa, Suhu outlet (T2) $222^{\circ} \mathrm{C}$, Tekanan inlet (P1) 3.1 Mpa, Suhu inlet (T1) $70^{\circ} \mathrm{C}$, dan Efisiensi Boiler 80\% dengan Laju Steam 20-22 t/jam.

Pada PKS Sei Pagar rasio produksi cangkang, serabut dan POME terhadap TBS adalah $7 \%, 13 \%$ dan $70 \%{ }^{4}$. Nilai rasio produksi cangkang dan serabut tersebut, sama dengan nilai rata-rata rasio cangkang dan serabut di PKS-PKS seluruh Sumatera Utara ${ }^{5}$.

\section{Tujuan Penelitian}

Makalah ini mengulas kajian Pemanfaatan Biogas POME sebagai Bahan Bakar Boiler untuk Pabrik Kelapa Sawit. Dari hasil evaluasi terhadap pemanfaatan Biogas POME di PLTBg wilayah Sumatera dan Kalimantan terdapat tiga skema Model Pemanfaatan secara umum di PKS, yaitu:

a) Skema Pertama (1-2-3-4) : Biogas POME hasil Treatment selain digunakan untuk bahan bakar gas engine, juga dimanfaatkan sebagai bahan bakar pengganti cangkang di boiler PKS.

b) Skema Kedua (1-2-4) : Biogas POME hasil Treatment hanya digunakan untuk bahan bakar pengganti cangkang di boiler PKS.

c) Skema Ketiga (1-4) : Biogas POME tanpa Treatment langsung digunakan untuk bahan bakar pengganti cangkang di boiler PKS. 


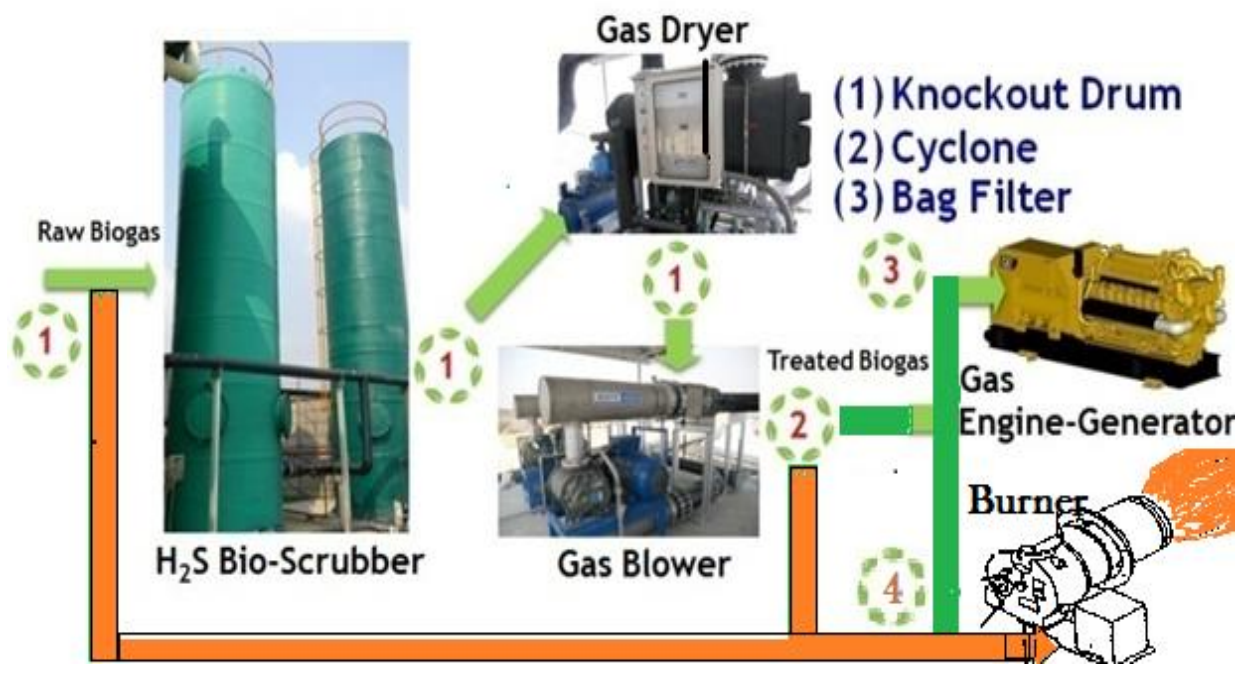

Gambar 1.

Skema model pemanfaatan secara umum di PKS

Skema Pertama, merupakan skema yang paling sesuai untuk lingkungan di PTPN V, karena produksi listrik yang dihasilkan dari biogas POME secara langsung telah dimanfaatkan ke pabrik, dan dimungkinkan untuk subtitusi cangkang dengan menerapkan teknologi Biogas to Boiler.

Skema ketiga, merupakan skema yang paling sesuai untuk PKS Sei Pagar, dan banyak dipilih terutama di wilayah Kalimantan oleh karena nilai investasi yang lebih murah dan menguntungkan, namun dampak lingkungannya sejauh ini tidak terlalu mengkhawatirkan.

Parameter keekonomian IRR dan NPV digunakan untuk mengevaluasi keekonomian pemanfaatan Biogas POME untuk mensubstitusi Cangkang.

\section{BAHAN DAN METODE}

Penelitian ini merupakan penelitian kuantitatif dengan pengumpulan data-data lapangan. Untuk data TBS olah PKS Sei-Pagar, Pengukuran COD, pH dan suhu POME, dilakukan di kolam IPAL (Instalasi Pengolahan Air Limbah), pada saat PKS beroperasi dalam kondisi yang sama. Waktu penelitian dilakukan antara bulan Juni 2018 dan Oktober 2018, di PKS Sei-pagar.

\section{Bahan}

Estimasi potensi gas metana diambil dari perhitungan NPV, IRR, dan POT, serta Perhitungan Pendapatan dari Cangkang. Dari sisi keekonomian Pemanfaatan Biogas POME (gas metana) dalam teknologi Biogas to Boiler secara teoritis terbukti menguntungkan melalui hasil substitusi cangkang, namun secara riil masih perlu kajian lebih lanjut yang terkait dengan kapasitas produksi PKS, lokasi dan nilai jual cangkang di pasaran setempat.

\section{Metode Desain Peralatan Sistem Gas}

Salah satu target dari Kajian Pemanfaatan Biogas Sebagai Bahan Bakar Boiler di Pabrik Kelapa Sawit adalah diperoleh Model/ Desain Peralatan Sistem Gas Burner, khususnya yang sesuai untuk modifikasi sistem pembakaran Boiler/ Ketel Uap, yang akan digunakan sebagai model pemanfaatan Biogas POME. Desain didapat melalui perhitungan analisa pembakaran bahan bakar cangkang dan serabut, serta analisa pembakaran Biogas POME. Kemudian desain, perhitungan dan pemilihan peralatan teknologi Biogas to Boiler, meliputi :

Blower, Sistem Pemipaan, Valve Train, Gas Burner (Single Burner), Forced Draft Fan, dan Control Panel/ PHB

sampel limbah cair yang diukur dari keluaran fat-pit diasumsikan dalam range yang tidak berbeda jauh di PKS dibawah manajemen PTPN V, yang kemudian digunakan sebagai inlet untuk reaktor biogas.

\section{Metoda}

\section{Metoda Pengambilan Sampel, Data dan Kuesioner}

Kajian Pemanfaatan Biogas POME sebagai Bahan Bakar Boiler ini merupakan penelitian kuantitatif dengan pengumpulan data-data lapangan : hasil dari pengambilan dan pengujian sampel di Laboratorium; dan data dari hasil studi banding : hasil Kuesioner Kajian Teknis dan Keekonomian Pabrik Kelapa Sawit di Wilayah 
Sumatera dan Kalimantan, maka dapat diketahui potensi PKS, untuk dianalisa secara teknis maupun keekonomian.

\section{Metoda Analisa Perhitungan}

Kajian Teknis dilakukan melalui perhitungan Neraca Panas dan Massa, dan perhitungan lainnya. Kajian ini digunakan untuk mengetahui potensi pembakaran bahan bakar cangkang dan serat, serta potensi pembakaran Biogas POME (gas metana), berdasarkan hasil analisa : COD, nilai rata-rata TBS olah dan rasio POME. Kemudian ditambahkan dengan beberapa catatan operasional/ lapangan Boiler di PKS, (sebelum dan sesudah menggunakan Biogas POME) dari hasil Kuesioner Kajian Teknis dan Keekonomian, sehingga dapat diketahui secara detail kondisi teknis yang diperlukan untuk evaluasi pemanfaatan Biogas POME, khususnya untuk modifikasi peralatan pada Boiler/ Ketel Uap.

Kajian Keekonomian dilakukan melalui perhitungan ekonomis dari data operasional Boiler atau Ketel Uap untuk kurun waktu tertentu yang dimaksudkan untuk mengetahui Harga Produksi Biogas. Analisa Kelayakan meliputi p

\section{Kajian Teknis / Karakteristik Biogas}

\section{Analisis Pembakaran Bahan Bakar Cangkang dan Serat}

Analisis pembakaran bahan bakar Cangkang (Shell) dan Serat (Fibre) dihitung untuk mengetahui potensi energi dari penggunaan cangkang dan serat, kemudian dapat dihitung energi untuk keperluan pembangkitan uap pada Boiler, dan minimum keluaran (Throughput) untuk operasi Boiler, melalui persamaan berikut :

Energi Fibre (Available) $\left(E_{f w}\right)=$ Fibre/FFB $x$

Throughput $x$ Calorific Value

Energi Shell (Available) $\left(E_{s w}\right)=$ Shell/FFB $x$

Throughput $x$ Calorific Value

\section{Analisis Pembakaran Bahan Bakar Biogas POME}

Mempelajari reaksi pembakaran biogas yang terdiri dari pembakaran gas metana, dan pembakaran gas $\mathrm{H}_{2} \mathrm{~S}$. Kemudian dihitung volume gas yang dihasilkan dari setiap pembakaran. Dilakukan perhitungan nilai kalor total dari biogas, jumlah udara teoritis untuk pembakaran, persentase gas hasil pembakaran, dan perkiraan excess air yang dibutuhkan dalam praktiknya.

Reaksi pembakaran pada gas metana adalah

$\mathrm{CH}_{4}+2 \mathrm{O}_{2}$ $\mathrm{CO}_{2}+2 \mathrm{H}_{2} \mathrm{O}+$ $37.705,49 \mathrm{~kJ} / \mathrm{m}^{3}$
Dengan persentase $66 \%$ volume gas metana yang terkandung, maka kalor yang dihasilkan dari pembakaran $1 \mathrm{~m}^{3}$ gas metana= $37.705,49 \times 0,66=24.885,6234 \mathrm{~kJ}$.

Reaksi pembakaran pada gas $\mathrm{H}_{2} \mathrm{~S}$ adalah $\mathrm{H}_{2} \mathrm{~S}+1,5 \mathrm{O}_{2} \longrightarrow \mathrm{SO}_{2}+\mathrm{H}_{2} \mathrm{O}+$ $23.957,14 \mathrm{~kJ} / \mathrm{m}^{3}$.

Dengan asumsi persentase $0,18 \%$ volume gas $\mathrm{H}_{2} \mathrm{~S}$ yang terkandung, maka kalor yang dihasilkan dari pembakaran $1 \mathrm{~m}^{3}$ gas $\mathrm{H}_{2} \mathrm{~S}=$ $23.957,14 \times 0,0018=43,12 \mathrm{~kJ}$.

Pada perhitungan diambil excess air sebesar $10 \%$.

\section{Analisis Neraca Panas dan Massa}

Dilakukan perhitungan density masingmasing komponen gas, yang secara umum densitas dapat dihitung dari persamaan berikut:

$$
\rho=M / v
$$

dimana :

$\mathrm{M}=$ Berat Molecular Biogas POME yang terdiri dari $\mathrm{CH}_{4}(16,0426), \mathrm{CO}_{2}(44,009), \mathrm{O}_{2}$ $(31,998), \mathrm{H}_{2} \mathrm{~S}(34,08)$

$\mathrm{v}=$ Volume

Densitas aktual total gas diperoleh dengan memperhitungkan komposisi sampel Biogas POME yang dihasilkan. Kemudian dilakukan perhitungan neraca massa komponen dan menghitung jumlah energi yang dihasilkan.

\section{Analisa Keekonomian}

Sebelum melakukan investasi perlu dilakukan perhitungan ekonomi agar proyek yang dijalankan, dinilai layak secara finansial. Apabila perhitungan yang dilakukan salah akan mengakibatkan kerugian, diantaranya hilangnya kesempatan dalam mendapatkan keuntungan (loss opportunity) dan kerugian terhadap biaya investasi yang telah dikeluarkan. Metodologi yang digunakan adalah metode life cycle costing approach yang mempertimbangkan seluruh biaya dan manfaat yang akan diperoleh di kemudian hari (in the future) dan mempertimbangkan nilai waktu dari uang (time value of money). Analisa ekonomi dilakukan dengan menyusun proyeksi keuangan meliputi proyeksi biaya-biaya produksi dan pendapatan, proyeksi laba-rugi, proyeksi cash flow, serta tingkat kelayakan proyek. Indikator kelayakan proyek yang akan digunakan meliputi:

1) Break Even Point of Sales (BEP of Sales) Menunjukkan gambaran tentang titik pulang pokok penjualan tiap tahun proyeksi, dihitung dengan formula: 


$$
\text { BEP of sales }=\frac{\text { Fixed cost }}{1-\frac{\text { Variable cost }}{\text { Sales }}}
$$

2) Net Present Value (NPV)

NPV merupakan selisih antara pengeluaran dan pemasukan yang telah didiskon dengan menggunakan biaya modal (cost of capital) sebagai diskon faktor, atau dengan kata lain merupakan arus kas yang diperkirakan pada masa yang akan datang yang didiskonkan pada saat ini. Untuk menghitung NPV diperlukan data tentang perkiraan biaya investasi, biaya operasi, dan pemeliharaan serta perkiraan manfaat/ benefit dari proyek yang direncanakan. Rumus NPV sebagai berikut:

$$
\mathrm{NPV}=\sum_{\mathrm{t}=1}^{\mathrm{N}} \frac{\mathrm{NCF}}{(1+\mathrm{k})}-\mathrm{I}_{\mathrm{o}}
$$

dimana

$\mathrm{NCF}=$ Arus kas bersih pada periode $\mathrm{t}$

$\mathrm{I}_{\mathrm{o}}=$ Pengeluaran investasi mula-mula

$\mathrm{k}=$ Biaya modal

$\mathrm{N}$ = Periode investasi

3) Internal Rate of Return (IRR)

IRR dihitung dengan mencari tingkat diskon (discount rate) yang dapat menghasilkan nilai net present value sama dengan nol. Artinya bahwa jumlah present value dari penerimaan selama umur proyek (project life) dengan tingkat diskon tersebut sama dengan jumlah present value dari pengeluarannya. Apabila hasil perhitungan IRR lebih tinggi dibandingkan dengan rata-rata tingkat biaya modal (Weighted Average of Cost of CapitalWACC) dari total dana yang digunakan dalam investasi proyek, maka proyek disimpulkan layak (feasible) secara finansial. Selain perhitungan indikator kelayakan, pada analisa ekonomi ini disajikan analisa sensitivitas yang merupakan analisa perhitungan untuk mengetahui perubahan indikator kelayakan suatu investasi atau bisnis akibat adanya perubahan parameterparameter seperti perubahan harga, kinerja produksi dan lain-lain. Parameter yang akan dianalisa yaitu perubahan harga jual cangkang dan nilai investasi barang modal.

\section{Lingkungan}

\section{Emisi GRK dari Penangkapan Gas Metana}

Aktivitas kegiatan/ proyek ini terdiri dari menangkap dan membakar gas metana yang dilepaskan dari kolam anaerob pengolahan air limbah yang dihasilkan dari pabrik kelapa sawit Sei Pagar yang dimiliki oleh PTPN V. Pabrik kelapa sawit tersebut memproses sekitar 170.858 ton Tandan Buah Segar (TBS) pada tahun 2017 dan menghasilkan limbah cair POME sekitar $136.686 \mathrm{~m}^{3}$ per tahun (Tabel 1). Proses ekstraksi minyak sawit menghasilkan sekitar limbah cair (POME) sekitar $0,8 \mathrm{~m}^{3}$ limbah cair minyak sawit (POME) untuk setiap ton TBS diproses.

Tabel 1.

\begin{tabular}{|c|c|c|c|}
\hline $\begin{array}{c}\text { Data kunci } \\
\text { untuk } \\
\text { kondisi } \\
\text { dasar } \\
\end{array}$ & Nilai & Unit & Sumber \\
\hline $\begin{array}{l}\text { Rasio } \\
\text { POME/TBS }\end{array}$ & 0,6 & $\begin{array}{l}\mathrm{m}^{3} \text { POME/ } \\
\text { ton TBS }\end{array}$ & PTPN V \\
\hline$Q_{y, w w}$ & $\begin{array}{l}\text { Lihat } \\
\text { Tabel } \\
2\end{array}$ & $\mathrm{~m}^{3}$ & PTPN V \\
\hline $\begin{array}{l}\text { COD y,ww, } \\
\text { untreated }\end{array}$ & $\begin{array}{l}\text { Lihat } \\
\text { Tabel } \\
4\end{array}$ & $\mathrm{mg} / \mathrm{l}$ & $\begin{array}{l}\text { Hasil } \\
\text { laboratorium }\end{array}$ \\
\hline $\begin{array}{l}\text { MCF } \\
\text { ww,treatment }\end{array}$ & 0,8 & --- & $\begin{array}{l}\text { AMS-III.H, } \\
\text { Point } 7 \text { (b), } \\
\text { MCF lower } \\
\text { value } \\
\text { applies }\end{array}$ \\
\hline
\end{tabular}

Besaran Nilai Parameter

Dalam rangka pengurangan dampak terhadap lingkungan, POME yang akan dibuang ke lingkungan, akan diolah dulu di dalam serangkaian unit pengolah limbah cair, yang terdiri dari pendinginan, pengambilan minyak kembali, kolam anaerob dan kolam aerobik, untuk mengurangi BOD/ COD ke tingkat yang dapat diijinkan oleh peraturan yang berlaku. Pengolahan anaerob bahan organik di dalam kolam-kolam tersebut dibarengi dengan produksi biogas yang mengandung metana, dan dilepaskan secara bebas ke atmosfer.

Rencana aktivitas kegiatan adalah penangkapan biogas, pemanfaatan biogas untuk boiler yang selama ini menggunakan bahan bakar cangkang dan serat dan juga sedikit minyak diesel (pada saat start up dan shut down). Kelebihan biogas (jika ada) akan dibakar (flaring).

Skema pengolahan POME saat ini dapat dilihat pada Gambar 2. Skema proyek seperti ini dapat mengurangi emisi gas rumah kaca sebagaimana dulu pernah ada dalam skema program CDM (Clean Development Mechanism). 


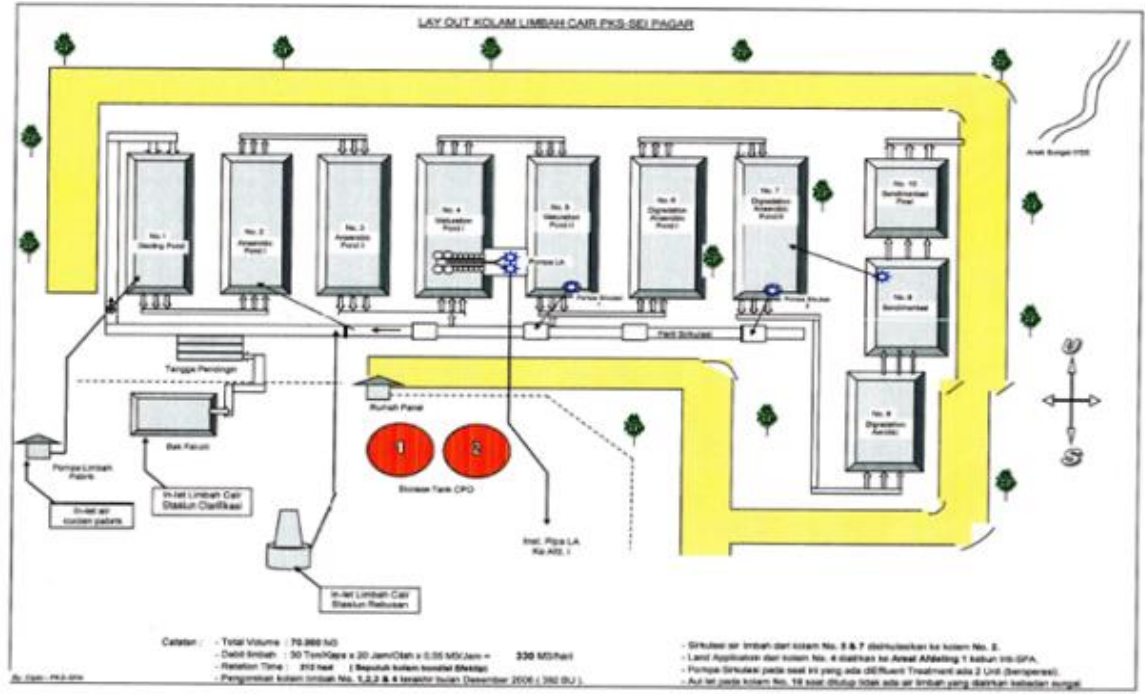

Gambar 2.

Layout Kolam Pengolahan PKS Sei Pagar (kondisi saat ini)

Kegiatan proyek terdiri dari penangkapan emisi biogas dari kolam anaerobik dengan dua kemungkinan teknologi reaktor yang berbeda, yaitu reaktor tangki jenis CSTR (continuous stirred tank reactor) dan reaktor cover CIGAR (Covered in ground Anaerobic Reactor) menutupi kolam dengan membran kedap air. Kegiatan penangkapan gas metana pada laporan ini menggunakan reaktor CSTR dengan alasan bahwa perolehan gas metana (biogas) dari reaktor CSTR ini relatif lebih baik dibandingkan dengan reaktor cover. Sedangkan investasi untuk reaktor CSTR relatif lebih mahal dibandingkan dengan reaktor CIGAR. Hal ini ditunjukkan pada gambar sebagai berikut.

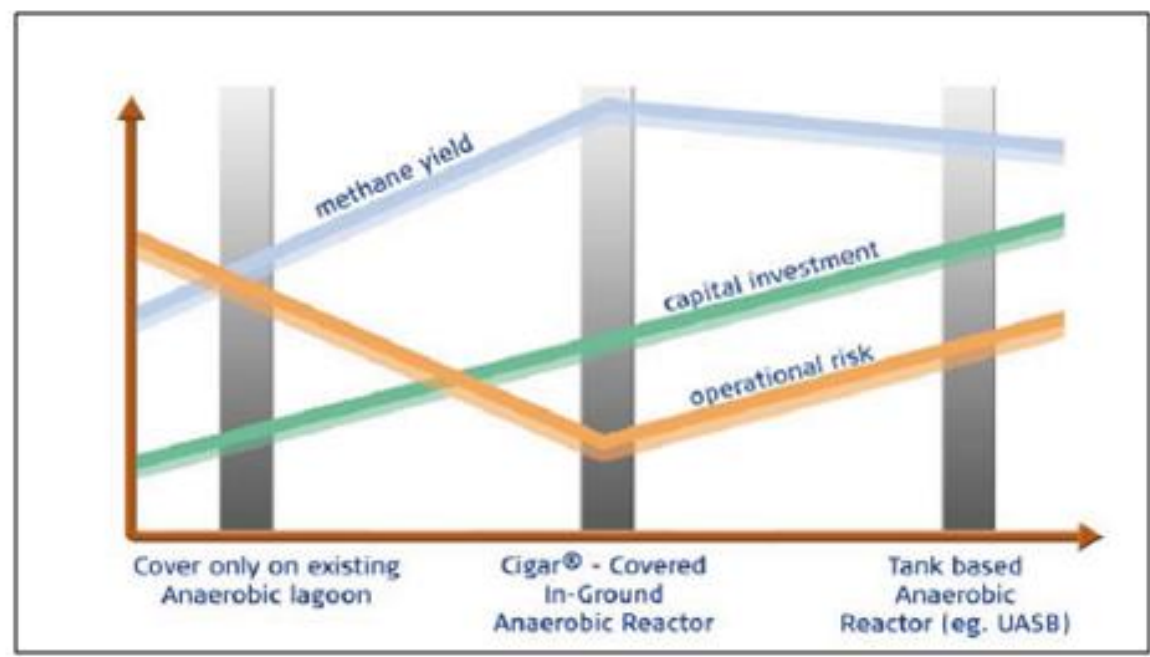

Gambar 3.

Perbandingan Perolehan Gas Metana dan Biaya Investasi untuk reactor CSTR dan CIGAR

\section{Perhitungan Pengurangan Emisi GRK}

Pengurangan emisi GRK proyek dihitung secara ex-ante, perhitungan pengurangan/ reduksi emisi GRK dihitung dengan menggunakan persamaan sebagai berikut.

$E R_{y, \text { ex ante }}=B E_{y, \text { ex }}$ ante $-\left(P E_{y, \text { ex ante }}+L E_{y, \text { ex ante }}\right)$
$E R_{y, e x}$ ante
$=E x$-ante pengurangan/ reduksi emisi GRK dalam tahun y ( $\left.\mathrm{tCO}_{2}-\mathrm{e}\right)$
$B E_{y, \text { ex ante }}=$ Ex-ante emisi baseline dalam tahun y $\left(\mathrm{tCO}_{2}-\mathrm{e}\right)$
$P E_{y, \text { ex ante }}=E x$-ante emisi proyek dalam tahun y $\left(\mathrm{tCO}_{2}-\mathrm{e}\right)$
$L E_{y, \text { ex ante }}=E x$-ante emisi kebocoran (leakage) dalam tahun y $\left(\mathrm{tCO}_{2}-\mathrm{e}\right)$

Dimana: 
Kajian Teknologi Pemanfaatan Biogas Pome (Palm Oil Mill Effluent) ke Boiler (Bambang Sucahyo, Dwi Lukman H, Rohmadi Ridlo, Tyas Puspita R, Erna Rosmala S)

\section{Data dan Parameter}

Asumsi yang digunakan dalam aktivitas proyek adalah penutupan semua kolam anaerob untuk menangkap gas metana yang timbul. Kondisi awal/ dasarnya adalah limbah cair anaerob tanpa pengambilan metana dan unit pembakaran. Kolam berupa tipe terbuka, dengan kedalaman di atas $4 \mathrm{~m}$ dan waktu tinggal minimal 30 hari. Temperatur effluent di atas $25^{\circ} \mathrm{C}$ sepanjang tahun. Gas metana dilepaskan ke atmosfer dalam kondisi yang tidak terkontrol.

Skenario emisi kondisi awal/ dasar terdiri dari potensi pembentukan gas metana pada pengolahan air limbah.

Tabel 2.

TBS/FFB diolah

\begin{tabular}{cccccc}
\hline Tahun & $\mathbf{2 0 1 3}$ & $\mathbf{2 0 1 4}$ & $\mathbf{2 0 1 5}$ & $\mathbf{2 0 1 6}$ & $\mathbf{2 0 1 7}$ \\
\hline FFB & 206.046 & 198.585 & 158.869 & 158.468 & 170.858 \\
POME1 & 123.627 & 119.151 & 95.321 & 95.081 & 102.515 \\
PKS $^{2}$ & 11.333 & 10.922 & 8.738 & 8.716 & 9.397 \\
$\begin{array}{c}\text { Palm } \\
\text { Fibre }\end{array}$ & 25.756 & 24.823 & 19.859 & 19.809 & 21.357 \\
$\begin{array}{c}\text { Operating } \\
\text { hour }\end{array}$ & 6.000 & 6.000 & 6.000 & 6.000 & 6.000 \\
\hline
\end{tabular}

Tabel 3.

Proyeksi TBS/FFB Diolah

\begin{tabular}{ccccccc}
\hline Tahun & $\mathbf{2 0 1 8}$ & $\mathbf{2 0 1 9}$ & $\mathbf{2 0 2 0}$ & $\mathbf{2 0 2 1}$ & $\mathbf{2 0 2 2}$ & $\mathbf{2 0 2 3}$ \\
\hline FFB & 170.858 & 175.129 & 179.507 & 183.995 & 188.595 & 193.310 \\
POME $^{1}$ & 102.515 & 105.078 & 107.704 & 110.397 & 113.157 & 115.986 \\
PKS $^{2}$ & 9.397 & 9.632 & 9.873 & 10.120 & 10.373 & 10.632 \\
$\begin{array}{c}\text { Palm } \\
\begin{array}{c}\text { Fibre } \\
\text { Operating } \\
\text { hour }\end{array}\end{array}$ & 21.357 & 21.891 & 22.438 & 22.999 & 23.574 & 24.164 \\
\hline
\end{tabular}

Tabel 4.

Data dan parameter untuk perhitungan Penurunan Emisi GRK

\begin{tabular}{|c|c|c|c|}
\hline $\begin{array}{l}\text { Data dan } \\
\text { Parameter }\end{array}$ & Nilai & Unit & Reference \\
\hline $\begin{array}{l}\text { Kapasitas } \\
\text { pabrik }\end{array}$ & 30 & $\begin{array}{l}\mathrm{mt} \text { FFB / } \\
\mathrm{hr}\end{array}$ & Kapasitas desain PKS \\
\hline $\begin{array}{l}\text { Jam operasi } \\
\text { PKS (hour per } \\
\text { day) }\end{array}$ & 20 & $\mathrm{hr} / \mathrm{d}$ & $\begin{array}{l}\text { Data (rata-rata untuk } \\
\text { tahun } 2015-2017 \text { ) }\end{array}$ \\
\hline $\begin{array}{l}\text { Operasi PKS } \\
\text { Tahunan (day } \\
\text { per year) }\end{array}$ & 300 & $\mathrm{~d} / \mathrm{yr}$ & $\begin{array}{l}\text { Historical data (data rata- } \\
\text { rata untuk tahun } 2015 \text { - } \\
2017 \text { ) }\end{array}$ \\
\hline t FFB / yr[a] & 162.732 & $\begin{array}{l}\mathrm{mt} \text { FFB / } \\
\mathrm{yr}\end{array}$ & $\begin{array}{l}\text { Data histori PKS, rata- } \\
\text { rata FFB diolah ( } 2015 \text { - } \\
2017)\end{array}$ \\
\hline $\begin{array}{l}\text { Mill operating } \\
\text { hour }(\mathrm{hr} / \mathrm{yr})\end{array}$ & 6.000 & $\mathrm{hr} / \mathrm{yr}$ & $\begin{array}{l}\text { Jam kerja rata-rata per } \\
\text { tahun }(2015-2017)\end{array}$ \\
\hline $\begin{array}{l}\text { COD raw } \\
\text { POME (masuk } \\
\text { ke sistem } \\
\text { anaerobik) }\end{array}$ & 50.000 & $\mathrm{mg} / \mathrm{l}$ & 10 days lab test \\
\hline
\end{tabular}

\begin{tabular}{|c|c|c|c|}
\hline $\begin{array}{l}\text { COD diolah } \\
\text { meninggalkan } \\
\text { anae. } \\
\text { treatment } \\
\text { system } \\
\text { (baseline) }\end{array}$ & 5.000 & $\mathrm{mg} / \mathrm{l}$ & 10 days lab test \\
\hline $\begin{array}{l}\text { COD dibuang } \\
\text { ke Kebun PKS } \\
\text { (baseline) }\end{array}$ & 5.000 & $\mathrm{mg} / \mathrm{l}$ & 10 days lab test \\
\hline $\begin{array}{l}\text { Bioreactor } \\
\text { COD removal } \\
\text { efficiency } \\
\text { (Project } \\
\text { activity) }\end{array}$ & $90 \%$ & & $\begin{array}{l}\text { Parameter Design } \\
\text { Bioreaktor }\end{array}$ \\
\hline $\begin{array}{l}\text { Final COD } \\
\text { Discharge } \\
\text { Limit to River }\end{array}$ & 125 & $\mathrm{mg} / \mathrm{l}$ & KLHK \\
\hline $\begin{array}{l}\text { Densiti dari } \\
\mathrm{CH}_{4}\end{array}$ & 0,716 & $\begin{array}{l}\mathrm{kgCH}_{4} / \mathrm{N} \\
\mathrm{m}^{3} \mathrm{CH}_{4}\end{array}$ & Tool for Methane Flaring \\
\hline $\begin{array}{l}\text { Konsentrasi } \\
\mathrm{CH}_{4}\end{array}$ & $60 \%$ & & Asumsi \\
\hline $\begin{array}{l}\text { LHV Biomass } \\
\text { (Cangkang wet } \\
\text { basis) }\end{array}$ & 18,8 & $\mathrm{MJ} / \mathrm{kg}$ & $\begin{array}{l}\text { Bio-Energy Potential of } \\
\text { Palm Kernel Shell, pg } 331\end{array}$ \\
\hline $\begin{array}{l}\text { LHV Biomass } \\
\text { (Fiber/ serat } \\
\text { wet basis) }\end{array}$ & 10,6 & $\mathrm{MJ} / \mathrm{kg}$ & $\begin{array}{l}\text { https://phyllis.nl/Biomass/ } \\
\text { View/2936 }\end{array}$ \\
\hline $\begin{array}{l}\text { Net Calorific } \\
\text { Value dari } \\
\text { Metana }\end{array}$ & 50,4 & $\mathrm{MJ} / \mathrm{kg}$ & $\begin{array}{l}\text { IPCC, default value, table } \\
1.2, \text { volume } 2\end{array}$ \\
\hline $\begin{array}{l}\text { Net Calorific } \\
\text { Value metana } \\
(\mathrm{MJ} / \mathrm{Nm} 3)\end{array}$ & 36,1 & $\begin{array}{l}\mathrm{MJ} / \\
\mathrm{Nm}^{3} \mathrm{CH}_{4}\end{array}$ & Dihitung \\
\hline
\end{tabular}

\section{HASIL DAN PEMBAHASAN}

\section{Kajian Teknis / Karakteristik Biogas Analisis Teknis Secara Umum}

Secara umum, Boiler/ Ketel Uap di PKS menggunakan serabut (11326 kJ/kg @ 50\% moisture) dan cangkang (23374 kJ / kg @ 10\% moisture) (sumber PKS PTPN V), sebagai bahan bakarnya untuk menghasilkan uap panas yang dipakai untuk mengolah kelapa sawit. Jumlah ketersediaan serabut dan cangkang secara teoritis dapat dihitung dari rasio masingmasing terhadap TBS, yaitu $13 \%$ dan $7 \%{ }^{4}$ ). Sebagian dari total potensi energi ini digunakan untuk memproduksi uap bagi kebutuhan proses minyak kelapa sawit dan pembangkit listrik, dan sisanya dijual ke pasar.

Kapasitas PKS Sei Pagar adalah 30 tonTBS/ jam. Rasio uap air yang dibutuhkan untuk membangkitkan listrik dan proses di PKS adalah 0,60 ton uap air/TBS ${ }^{6}$. Untuk PKS Sei Pagar, kapasitas produksi uap air sebanyak $18 \mathrm{t}$ tjam (=0,6 t-uap air/TBS $\times 30$ t-TBS/jam) dibutuhkan pengoperasian satu unit Boiler (Takuma), berkapasitas masing-masing 22 t/jam. Kebutuhan energi di tungku boiler dihitung berdasarkan perbedaan entalpi air di boiler inlet dan enthalpi uap air di boiler outlet.

Dari hasil Analisa Pembakaran Bahan Bakar Biomasa, dapat diketahui : Surplus Energi yang diperoleh dari pembakaran cangkang dan serabut, pada basis 20 jam per hari saat 
operasional; sebesar 20 jam per hari $\mathrm{x}$ $15060,88 \mathrm{~kg} / \mathrm{hr}=301,2176 \quad \mathrm{MT} /$ hari. Hal ini menunjukan adanya kelebihan dalam suplai bahan bakar kedalam ruang bakar, walaupun dalam proses produksi sering diabaikan karena kendala operasional seperti suplai bahan bakar dengan sesuai seperti memiliki kandungan M.C dan Nilai Kalor yang konstan memang sulit dilakukan.

Dari hasil Analisa Pembakaran Biogas POME, asumsi yang digunakan untuk produk $\mathrm{CH}_{4} 66 \%$, dalam biogas POME sangat relatif, mengingat kandungan itu dihasilkan dari proses pembentukkan Biogas POME dalam Digester oleh bakteri dalam cairan POME. Menjaga kestabilan kandungan $\mathrm{CH}_{4}$ dalam Biogas POME termasuk yang sulit dilakukan, karena selain teknik juga diperlukan kesabaran, karena keberadaan bakteri menjadi alasan dan perhatian utama untuk memantau keberhasilan proses digester. Kondisi ini tergantung operasional dari masing-masing PKS, sehingga untuk menerapkan standar minimal kandungan $\mathrm{CH}_{4}$ diperlukan pengalaman operasional. Pada studi banding pemanfaatan Biogas to Boiler di PKS Sungai Rungau Kalteng, standar suplai Biogas POME yang minimal ditetapkan mengandung $\mathrm{CH}_{4} 50 \%$, Dan kenyataannya, nilai kandungan tersebut berangsur-angsur terdegradasi dari awal Digester dioperasikan. Jika kandungan $\mathrm{CH} 4<50 \%$, maka untuk menjaga nilai pembakaran yang sesuai dengan kebutuhan energi di Boiler untuk menghasilkan uap panas, maka suplai Biogas POME ke Boiler perlu dihentikan sementara atau operasi Boiler ditunda, untuk memberi waktu bagi bakteri dalam Digester recovery, untuk menghasilkan Biogas POME sesuai standar suplai Biogas POME yang ditetapkan maka perhitungan neraca masa dilakukan pada boiler yaitu dimana terjadinya pembakaran biogas POME. Kalor yang terjadi pada pembakaran biogas berasal dari kontribusi kandungan metana yaitu sebesar $66 \%$, sedangkan kalor dari pembakaran $\mathrm{H}_{2} \mathrm{~S}$ dapat diabaikan karena jumlahnya yang sangat kecil, 0,1\%. Pembakaran biogas menggunakan udara menggunakan FD Fan (Force Draft Fan). Kebutuhan udara pembakaran dihitung dari stoikiometri pembakaran metana, yang mana merupakan kebutuhan udara teoritis. Pada kenyataannya kebutuhan udara harus lebih besar dari teoritis atau yang disebut excess air. Excess air pada pembakaran biogas 10\%, dimana jika excess air yang terlalu kecil dapat mempengaruhi kualitas pembakaran sedangkan jika terlalu besar dapat menjadi rugi-rugi pembakaran.

Komponen masuk ke dalam boiler berasal dari biogas dan yaitu $\mathrm{CH}_{4}, \mathrm{CO}_{2}, \mathrm{H}_{2} \mathrm{O}, \mathrm{H}_{2} \mathrm{~S}, \mathrm{O}_{2}$ dan $\mathrm{N}_{2}$. Kandungan $\mathrm{CO}_{2}$ dan $\mathrm{H}_{2} \mathrm{~S}$ masuk ke dalam boiler karena tidak dilakukan treatment biogas. $\mathrm{O}_{2}$ dan $\mathrm{N}_{2}$ berasal dari udara yang dialirkan menggunakan FD Fan. Sedangkan gas buang dari boiler terdiri dari $\mathrm{CO}_{2}, \mathrm{H}_{2} \mathrm{O}, \mathrm{N}_{2}$ dan $\mathrm{SO}_{2}$. $\mathrm{SO}_{2}$ berasal dari pembakaran $\mathrm{H}_{2} \mathrm{~S}$ dari biogas yang tidak di-treatment. Kandungan $\mathrm{H}_{2} \mathrm{~S}$ yang sangat kecil, sekitar $0,1 \%$, menghasilkan $\mathrm{SO}_{2}$ sekitar 0,03\%. Dari hasil studi di lapangan pada $\mathrm{PKS}$ yang dikunjungi, nilai kandungan $\mathrm{SO}_{2}$ sebesar ini masih masuk dalam baku mutu lingkungan emisi gas buang.

\section{Hasil Skema Model - Peralatan Sistem Gas Burner}

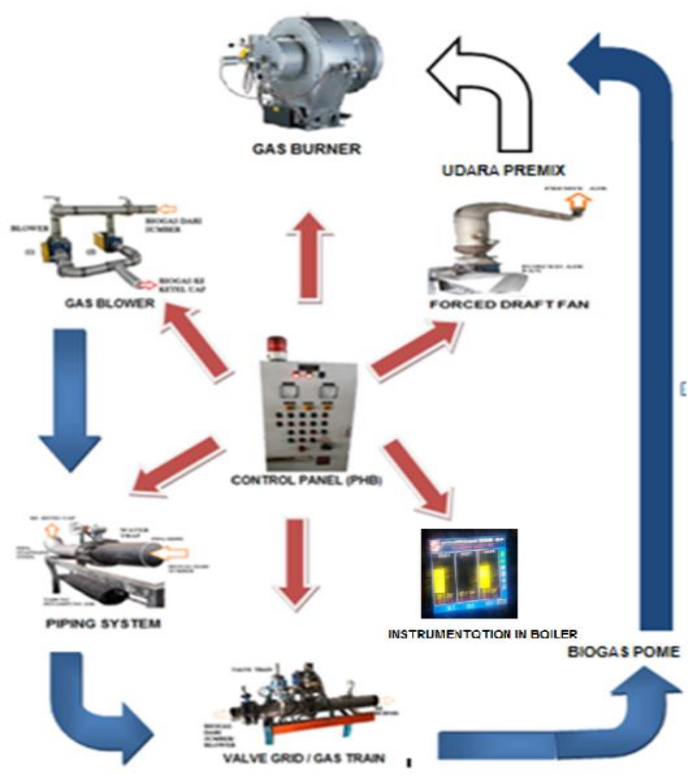

Gambar 4

Skema Model Pemanfaatan Biogas POME ke Boiler di PKS Sei Pagar 
1. Blower

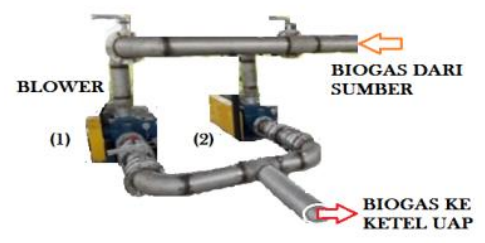

2. Sistem Pemipaan
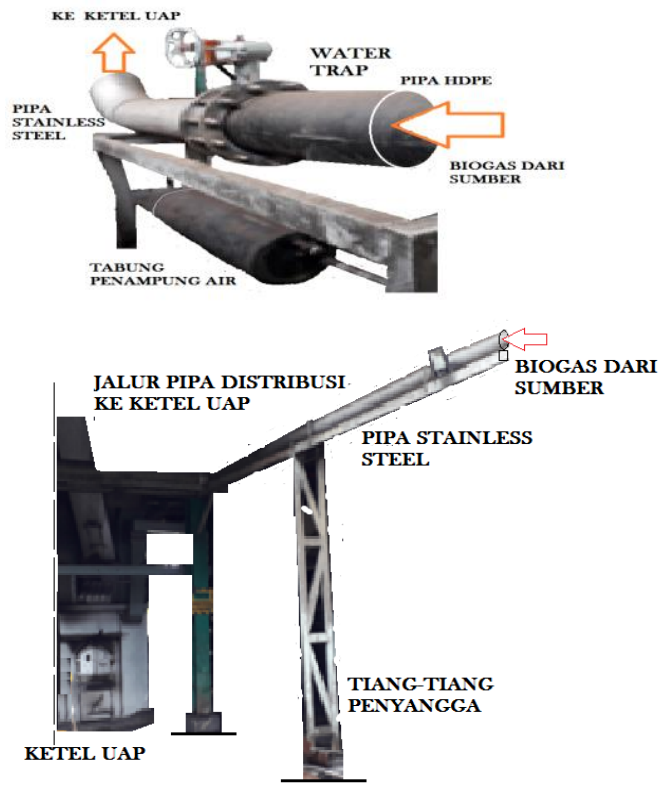

3. Valve Train

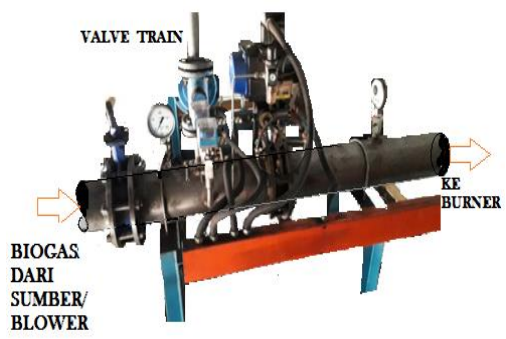

4. Gas Burner (Single Burner)

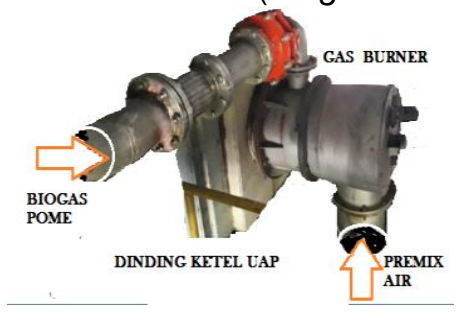

5. Forced Draft Fan

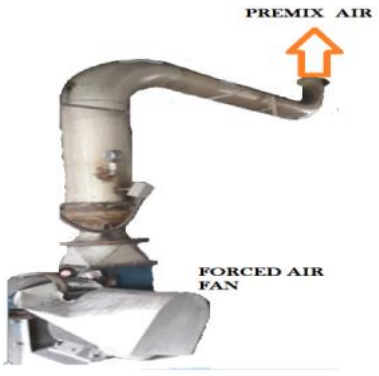

6. Control Panel/ PHB

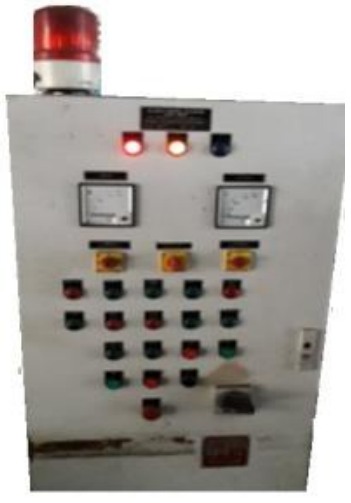

Desain peralatan didasarkan dari data-data hasil studi banding, hasil perhitungan teknis, serta pemilihan peralatan (Gas Burner Catalogue) yang disesuaikan dengan kondisi lapangan. Dalam penerapannya, modifikasi diperlukan guna menyesuaikan dengan kebutuhan dan pemasangannya. Hal yang berkaitan dengan desain dan hasilnya secara terinci belum dijabarkan disini, karena masih akan dilanjutkan tahun berikutnya.

\section{Kajian Keekonomian dan Lingkungan Analisis Keekonomian Secara Umum Kebutuhan Investasi}

Pembangunan proyek ini diperkirakan akan selesai dalam waktu satu tahun. Biaya investasi meliputi reaktor biogas dan sistem burner. Untuk mendanai investasi berasal dari dua sumber yaitu modal sendiri (equity) dan pinjaman (debt) bank dengan rasio debt : equity $=70 \%: 30 \%$. Tingkat bunga kredit bank diasumsi sebesar $10 \%$ per tahun.

\section{Perhitungan Biaya Produksi Biogas}

Biaya produksi biogas terdiri dari biaya produksi variabel dan biaya produksi tetap. Biaya produksi variabel meliputi biaya utilitas (air, bahan bakar genset, dan lainnya). Sementara itu, biaya produksi tetap meliputi biaya upah tenaga kerja, overhead dan administrasi, biaya perawatan tahunan, serta biaya depresiasi dan asuransi.

\section{Perhitungan Pendapatan dari Cangkang}

Biogas yang dihasilkan dari reaktor akan digunakan untuk bahan bakar cangkang untuk boiler. Oleh karena itu, dengan adanya biogas, maka limbah cangkang dapat dijual ke pasaran. Dari hasil perhitungan dalam waktu satu tahun produksi, jumlah cangkang yang dapat digantikan dengan biogas sebanyak 6.549,3 ton per tahun. Dengan harga cangkang sebesar Rp 4.000 per $\mathrm{kg}$ atau $\mathrm{Rp} 400.000$ per ton, maka 
pendapatan yang diperoleh dari hasil penjualan cangkang sekitar Rp 2,62 Milyar.

\section{Proyeksi Laba-Rugi}

Hasil proyeksi perhitungan laba-rugi menunjukkan perolehan laba bersih yang positif dari tahun pertama dan terus meningkat pada tahun-tahun berikutnya. Hal ini menunjukkan bahwa hasil dari penjualan cangkang dapat menutup biaya produksi biogas.

\section{Perhitungan Kelayakan Proyek}

Hasil perhitungan Internal Rate of Return (IRR) proyek memberikan nilai sebesar $11,36 \%$. Dengan tingkat bunga rata-rata tertimbang (WACC) dihitung pada $11 \%$ per tahun, Net Present Value (NPV) menghasilkan angka positif yang menunjukkan bahwa proyek tersebut layak secara finansial. Perhitungan Payback Period menunjukkan waktu pengembalian investasi ini setelah 6,56 tahun.

\section{Analisis Lingkungan Secara Umum}

Hasil pengurangan emisi GRK proyek dihitung secara ex-ante, perhitungan pengurangan/ reduksi emisi GRK dihitung dengan menggunakan persamaan-persamaan berikut, dan dirangkum pada Tabel 5 .

Adapun total Estimasi Pengurangan Emisi (ex-ante) dijabarkan pada Tabel 6 di bawah ini, yang besarnya diperkirakan $117.762 \mathrm{tCO}_{2 \mathrm{e}}$ selama periode keseluruhan 7 tahun (20182024). Pengurangan emisi maksimum dapat dicapai jika pabrik kelapa sawit yang digunakan mencapai kapasitas maksimumnya. Jumlah sebenarnya dari pengurangan emisi akan dihitung ex-post berdasarkan produksi aktual. :

Tabel 5.

Nilai Pengurangan Emisi (ex-ante)

\begin{tabular}{|c|c|c|c|}
\hline \multicolumn{4}{|c|}{$\begin{array}{l}\text { Persamaan 17: } E R_{y, \text { ex ante }}=B E_{y, \text { ex ante }}-\left(P E_{y, \text { ex ante }}+\right. \\
\left.L E_{y, \text { ex ante }}\right)\end{array}$} \\
\hline$E R_{y, e x \text { ante }}$ & $\begin{array}{l}\text { Pengurangan } \\
\text { emisi ex ante } \\
\text { dalam tahuny } \\
\text { (tCO2e) }\end{array}$ & 8.935 & $\begin{array}{l}\text { Persamaan } \\
17\end{array}$ \\
\hline$B E_{y, \text { ex ante }}$ & $\begin{array}{l}\text { Emisi baseline } \\
\text { ex ante dalam } \\
\text { tahuny } \\
(\mathrm{tCO} 2 \mathrm{e})\end{array}$ & 15.560 & $\begin{array}{l}\text { Persamaan } \\
2\end{array}$ \\
\hline$P E_{y, \text { ex ante }}$ & $\begin{array}{l}\text { Emisi proyek } \\
\text { ex ante dalam } \\
\text { tahuny } \\
\text { (tCO2e) }\end{array}$ & 6.625 & $\begin{array}{l}\text { Persamaan } \\
7\end{array}$ \\
\hline$L E_{y, \text { ex ante }}$ & $\begin{array}{l}\text { Emisi leakage } \\
\text { ex ante dalam } \\
\text { tahuny } \\
\text { (tCO2e) }\end{array}$ & 0 & $\begin{array}{l}\text { Persamaan } \\
16\end{array}$ \\
\hline
\end{tabular}

Tabel 6.

Rangkuman Estimasi

Pengurangan Emisi (ex-ante)

\begin{tabular}{lllll}
\hline Tahun & $\begin{array}{l}\text { Estimasi } \\
\text { emisi } \\
\text { aktivitas } \\
\text { proyek } \\
\text { (tCO } \mathbf{2})\end{array}$ & $\begin{array}{l}\text { Estimasi } \\
\text { emisi } \\
\text { baseline } \\
\left.\mathbf{( t C O}_{\mathbf{2}} \mathbf{)}\right)\end{array}$ & $\begin{array}{l}\text { Estimasi } \\
\text { leakage } \\
\left.\mathbf{( t C O}_{\mathbf{2}} \mathbf{)}\right)\end{array}$ & $\begin{array}{l}\text { Estimasi } \\
\text { pengurangan } \\
\text { emisi } \\
\text { keseluruhan } \\
\left.\mathbf{( t C O}_{\mathbf{2}} \mathbf{e}\right)\end{array}$ \\
\hline 2018 & 6.625 & 15.560 & 0 & 8.935 \\
2019 & 6.787 & 15.987 & 0 & 9.200 \\
2020 & 6.953 & 16.342 & 0 & 9.389 \\
2021 & 7.123 & 16.784 & 0 & 9.661 \\
2022 & 7.298 & 17.169 & 0 & 9.871 \\
2023 & 7.476 & 17.611 & 0 & 10.135 \\
2024 & 7.660 & 18.309 & 0 & 10.379 \\
Total & 49.922 & 117.762 & $\mathbf{0}$ & 67.570 \\
$\mathbf{( 7 ~ t h n ) ~}$ & & & & \\
\hline
\end{tabular}

\section{SIMPULAN}

Kajian Teknis Pemanfaatan Biogas sebagai bahan bakar Boiler yang mengambil studi kasus di PLTBg Sei Pagar, telah melewati tahapan Pra Desain khususnya teknologi Biogas to Boiler. Namun perlu untuk tidak saja mengkaji dari sisi perkembangan dan penerapan teknologi, tetapi harus juga di dukung oleh Kajian Keekonomian dan Lingkungan.

Dari sisi ekonomi, faktor terpenting adalah skenario kebijakan pemerintah yang terkait dengan harga jual listrik dapat berpengaruh terhadap iklim investasi PLTBg di PKS secara keseluruhan. Untuk mengoptimalkan pemaanfaatan gas metane (biogas) yang dihasilkan, upaya PLTBg Sei Pagar dengan memanfaatkan Biogas POME (metana) sebagai subtitusi Cangkang di PKS, dan menjual kelebihan Cangkang tersebut dapat menjadi sumber tambahan pendapatan untuk meningkatkan keuntungan ekonomis PLTBg.

Secara singkat, Kajian Lingkungan memfokuskan pada hasil pengurangan Emisi GRK, hal ini menjadi catatan penting bagi keberadaan dan tanggung jawab PKS terhadap lingkungan di sekitarnya.

Faktor peningkatan Tingkat Kandungan Dalam Negeri (TKDN) dan harga jual listrik merupakan komponen penting dalam peningkatan nilai keekonomian PLTBg, karena mempunyai dampak untuk menurunkan investasi. Hal ini merupakan hal yang perlu dipikirkan untuk kelanjutan pembangunan PLTBg di PKS, sebagai dampak dari diberlakukannya Permen ESDM No.12/2017.

\section{DAFTAR PUSTAKA}

1. Peraturan Presiden, No. 5 tahun 2006, Tentang Kebijakan Energi Nasional, 2006.

2. Mun, Y.W., Production Of Methane From Palm Oil Mill Effluent By Using Ultrasonicated Membrane Anaerobic System (UMAS), Faculty of Chemical and 
Natural Resources Engineering Universiti Malaysia Pahang, 2012.

3. Sihombing, A., and et. al., Analisis Perhitungan Ekonomi dan Potensi Penghematan Energi Listrik pada Pembangkit Listrik Tenaga Uap di Pabrik Kelapa Sawit PT. X, Jurnal Reka Elkomika (Jurnal On line Institut Teknologi Nasional), 2 (2), 90-96, 2014.

4. Febijanto, I. Tinjauan Komponen Harga Jual Tenaga Listrik dari Pembangkit Listrik Tenaga Biogas denganTeknologi Covered lagoon, Prosiding Seminar Nasional Kimia, 13 Mei 2017, Hotel Grand Quality, Yogyakarta, 72-73, 2017.

5. Pricilia, S.A., Analisis Ekonomi Pemanfaatan Fiber dan Cangkang Kelapa Sawit Menjadi Energi Listrik, Studi Kasus: PT. Bahan Karya Semesta, Kab. Sarolangun, Jambi, Skripsi Sarjana, Dept. Ekonomi Sumber daya dan Lingkungan, Fak. Ekonomi dan Manajemen, Institut Pertanian Bogor, pp.53, 2014.

6. Bakar, N.A., Soon, L.W, Sukiran, M.A., Kheang, L.S., dan Bukhari, N.A., Co-firing of Biogas in Palm Oil Mill Biomass Boilers, PALM OIL ENGINEERING BULLETIN NO. 120, November 2017.

7. Abas, R., Abdullah, R., dan Hawari, Y., Economic Feasibility Study on Establishing an Oil Palm Biogas Plant in Malaysia, Oil Palm Industry Economic Journal Vol. 13 (1), Maret 2013.

8. Liew, W.L., Kassim, M.A., Muda, K., dan Loh, S.K., Feasibility Study on Plam Oil Processing Wastes Towards Achieving Zero Dixcharge, ARPN Journal of Engineering and Applied Sciences, Vol. 11, No. 4, February 2016.

9. Maryana, R., Satriyo K.W., dan Kismurtono, M., Proses Pemurnian Metana dari Biogas Menggunakan Larutan $\mathrm{NaOH}$ Dan $\mathrm{KOH}$, Seminar Nasional Fundamental Dan Aplikasi Teknik Kimia, Surabaya, 2008.

10. Sugiarto, Oerbandono, T. Widhiyanuriyawan, D., dan Putra, F.S.P., Purifikasi Biogas Sistem Kontinyu Menggunakan Zeolit, Jurnal Rekayasa Mesin Vol.4, No.1 Tahun 2013.

11. Ryckebosch, E., Drouillon, M., dan Vervaeren, $\mathrm{H}$., Techniques for transformation of biogas to biomethane, Biomass and Bioenergy 35, 2011.

12. Zhao, Q., Leonhardt, E., MacConnell, C., Frear, C., dan Chen, S., Purification Technologies for Biogas Generated by Anaerobic Digestion, CSANR Research Report, 2010.

13. Kadam, R., dan Panwar, N.L., Recent advancement in biogas enrichment and its applications, Renuable and Sustanable Energy Reviews 73, 2017.

14. Rachman, R., Caroko, N., dan Wahyudi, Perancangan, Pembuatan, Dan Pengujian Alat Pemurnian Biogas Dari Pengotor H2O Dengan Metode Pengembun (Kondensasi), Jurnal Teknik Mesin UMY 2017.

15. Budiman, A., Syarief, A., dan Isworo, H., Analisis Perpindahan Panas Dan Efisiensi Efektif High Pressure Heater (HPH) Di PLTU Asam-Asam, Jurnal IImiah Teknik Mesin Unlam Vol. 03, 2014.

16. Demirel, Y., Energy, Production, Conversion, Storage, Conservation and Coupling, Department of Chemical and Bio molecular Engineering University of Nebraska Lincoln N 16th St 820 Lincoln, NE 68588-0643 USA, 2012.

17. Maizirwan, M., Ibrahim, M.M.A., Setyobudi, R.H., Preliminary study of biogas upgrading and purification by pressure swing adsorption, AIP Conference Proceedings, 2016.

18. Nasution, M. A., and et. al., Analysis of Palm Biomass as Electricity from Palm Oil Mills in North Sumatera, Energy Procedia, 47: 166172, 2014.

19. PT KME (PT Karya Mas Energi). Biogas Bundled Project 2, ver. 12, 12/12/2012, https://cdm.unfccc.int/filestorage/h/n/RPK5 SJ0BC07FEHQ9IXAYL68WNG3V2Z.pdf/9 233-20121228-

PDD.pdf?t=eFI8b25sZW5qfDDUeCshWhm ew6EgRh6a3VSm, diakses 11 Januari 2017.

20. PT KME (PT Karya Mas Energi). Biogas Bundled Project, ver.13.0, 16/11/2012, https://cdm.unfccc.int/filestorage///c/0XZT8 K1WPODJFUIEV9MHSBQ5Y74CNA.pdf/8 944-\%20PDD-

2012\%2012\%2020.pdf?t=dIR8b25sZXV1fD D5hwJiSvvAnlei68580iin, diakses 11 Januari 2017.

21. PT KME (PT Karya Mas Energi). Biogas Bundled Project 3, ver. 12, https://cdm.unfccc.int/filestorage/3/n/JAO4F R9MLTEU3Z6BC8SXKQ5N2IDWVP.pdf/92 34\%20PDD.pdf?t=T1R8b25sZXItfDCn8Hd 1_5JsFbCQHdhvqF5A, diakses 15 Januari 2017.

22. Keputusan Menteri Energi dan Sumber Daya Mineral Republik Indonesia No. 1404 K/20/MEM/2017, tentang Besaran Pokok Penyediaan Pembangkitan PT PLN (Persero), 2017.

23. Abdullah, N. A., Mohamed, R., Wan Mahmood, W. M. F., dan Md Saad, M. H., Black smoke elimination via PID controlled co-firing technique at palm oil mill, International Journal of Applied Engineering Research, 12(19), 8050-8056, 2017. 
(halaman ini sengaja dikosongkan) 